\title{
Gii der faer en Diæffwel i ier! On the origins of Danish gid-sentences
}

\author{
TANYA KAROLI CHRISTENSEN
}

This paper unfolds part of the grammaticalization process behind a subtype of modern Danish emotive sentences, featuring the illocutionary particle gid 'I wish' /'If only'. The traditional etymological explanation of the lexicalization process of gid, which traces the origins to a prayer-like construction of Old Danish (Gud give det, lit. 'God give it', $>$ give $+\mathrm{t}>$ gid), is only part of the picture. At a point in the second part of the 17 th century when the originally sentenceformed construction had been reduced to the subjunctive verb form, occasionally with an enclitic pronominal object, an alternative form was also in use. This form is best understood as the imperative of give, and in the investigated texts it displays a much wider functional potential as it is used not only in good wishes (typically in religious contexts), but also profanely in 'bad wishes' (similar to a common form of curses). It is proposed that the subjunctive form initially is the marked variant, but that subsequent reanalyses interpret the imperative variant simply as a profanity, thus changing the markedness values and eventually leaving the imperative form obsolete. 